\title{
NOTES
}

\section{REVENUE RUL1NG 70-531: A CHANGE IN THE TREATMENT OF NON-DIVIDEND REDEMP- TIONS AT THE CORPORATE LEVEL?}

Corporation $\mathrm{X}$, the shares of which are held equally by $\mathrm{A}$ and $\mathrm{B}$, redeems all of A's shares in a qualifying section 302(b)(3) redemption. ${ }^{1}$ The corporation has a tax basis balance in its capital account of $\$ 80$ and $\$ 120$ in its accumulated earnings and profits account. The redemption price is $\$ 250$. In accordance with sections 312(a) and 312(e) of the Internal Revenue Code of $1954,{ }^{2}$ part of the redemption price is to be charged to the capital account of the redeeming corporation, and the remainder is to be charged to and, thereby, reduce the corporation's accumulated earnings and profits. Following nearly 30 years of precedent, ${ }^{3}$ Corporation X charges a portion of the redemption price equal to one-half the capital account against that account and reduces earnings and profits by the balance of the redemption price. The accumulated earnings and profits account thus equals zero after the redemption, ${ }^{4}$ and any distribution by $\mathrm{X}$ to $\mathrm{B}$ made immediately after the redemption will receive capital gains rather than ordinary income treatment. ${ }^{5}$

1. INT. REv. CODE of 1954, §302(b)(3). Under this section a complete redemption of all of a shareholder's stock entitles the shareholder to capital gains treatment on the redemption distribution. The corporation's treatment of the distribution is governed by $i d$. $\S 312$ (e).

2. Section $312(\mathrm{e})$ is applicable to both sections 302 and 303 redemptions and partial liquidations.

3. See F \& R Lazarus \& Co., I T.C. 292 (1942), acquiesced in, 1943 CUM. Bull. 14; William D.P. Jarvis v. Commissioner, 43 B.T.A. 439, aff d 123 F.2d 742 (4th Cir. 1941), acquiesced in, 1942-2 CuM. Bull. 10.

"[The IRS and a private party] . . agree that the portion of a redemption payment to be charged to [the capital] account . . . has been settled by William D.P. Jarvis . . ." Bennett $v$. United States, 427 F.2d 1202, 1216 (Ct. CI. 1970). See also notes 39-47 infra and accompanying text.

4. One half of the capital account equals $\$ 40$. After this is deducted from the redemption distribution of $\$ 250, \$ 210$ remains to reduce the accumulated earnings account. Since that account only contains $\$ 120$, it is reduced to zero after the distribution charge is made.

5. INT. REv. CODE of 1954, §§ 301(c) \& 316. Section 301 (c) provides that the portion of the distribution which is a dividend will be taxable as ordinary income. However, a dividend, according to section 316 , is a distribution made out of earnings and profits. Assuming that there is no present year earnings and profits, the distribution made by $\mathrm{X}$ to $\mathrm{B}$ cannot be a dividend since accumulated earnings and profits have been reduced to zero. Section $301(c)$ also provides that to the extent the distribution is not a dividend, it will receive capital gains treatment. 
According to the position taken by the Internal Revenue Service in Revenue Ruling $70-531,{ }^{6}$ the above charges to earnings and profits and capital accounts are no longer acceptable. Instead, in a nondividend redemption ${ }^{7}$ the Service maintains that earnings and profits should be reduced by the pro rata portion of X's earnings and profits attributable to the shares redeemed. The remainder of the redemption price is properly chargeable, in two steps, to the capital account which is incremented to include unrealized appreciation. ${ }^{8}$ The first charge, equal to the redeemed stock's ratable share of paid-in capital, is made to the stated capital and paid-in surplus accounts; the remaining redemption price is then charged to unrealized appreciation surplus. ${ }^{9}$ Thus, in the example given, the capital account and earnings and profits are reduced by $\$ 40$ and $\$ 60$ respectively - a 50 percent charge to each - and the remaining redemption distribution, $\$ 150$, is charged to unrealized appreciation surplus. As a result, earnings and profits are not completely eliminated and the first $\$ 60$ of a distribution made immediately after the redemption by Corporation $\mathrm{X}$ to $\mathrm{B}$ would be a taxable dividend. ${ }^{10}$

Deciding what portion of a non-dividend redemption distribution should reduce earnings and profits entails an analysis of section 312(e). That section states that "the part of such distribution which is properly chargeable to capital account shall not be treated as a distribution of earnings and profits," 11 and the portion of the distribution which is not so charged is charged to earnings and profits. ${ }^{12}$ Thus, determining what is "properly chargeable to capital account" is of paramount importance in arriving at the reduction of

6. 1970 INT. Rev. Bull. No. 42, at 7-10.

7. Non-dividend redemption is used to signifiy any section 302 or 303 redemption. The revenue ruling is also applicable to section 346 liquidating distributions; however, that topic is not discussed in this note.

8. I970 INT. REv. BULL. No. 42, at 10. In Revenue Ruling 70-531, the IRS has withdrawn its acquiescence in Lazarus, Jarvis, and Woodward Investment Co., 46 B.T.A. 648 (1942). The IRS has substituted nonacquiescence in Jarvis and acquiescence in result in Lazarus and Woodward. 1970 INT. REv. BuLL. No. 42, at 10.

9. 1970 INT. Rev. Bull. No. 42, at 10.

10. Id. See note 5 supra.

11. INT. Rev. CoDE of 1954, $\S 312(\mathrm{e})$. This section also applies to distributions in partial liquidations under section 346 . See note 7 supra.

12. INT. REv. CoDE of 1954, § 312(a), states that "except as otherwise provided in this section, on the distribution of property by a corporation with respect to its stock, the earnings and profits of the corporation . . . shall be decreased by the sum of [the property distributcd]." Section 312(e) excepts that portion of a distribution which is properly chargeable to capital account. The remaining distribution, if any, is treated in the manner provided in section 312(a). 
earnings and profits resulting from a redemption distribution to which section 312(e) applies.

\section{History of Section 312(e) Prior to Revenue Ruling 70-531}

The forerunner of section 312(e) was section 201(c) of the Revenue Act of $1924 .{ }^{13}$ Before the passage of section 201 (c), considerable attention had focused on the treatment to a shareholder upon a redemption distribution, but little consideration had been given to the corporate level tax treatment of such transactions. ${ }^{14}$ On one occasion prior to 1924, however, the IRS did note, in O.D. $479,{ }^{15}$ that a corporation, in redeeming part of its stock, must charge an amount equal to the stock's par value to the capital account and charge the remainder to surplus accumulated prior to March 1, 1913. ${ }^{16}$ After these two charges, no part of the redemption distribution remained, and, therefore, O.D. 479 did not consider what account would be affected after depletion of the pre-1913 earnings account. Thus, no allowance was made for a charge to post-March 1, 1913 earnings and profits although presumably such earnings were reflected in the redemption price.

The language of section 201(c) of the 1924 Code, being nearly identical with that of section 312(e), does not describe in any detail the method of determining the proper charge to the capital account and is, therefore, of little guidance in interpreting section 312(e). The legislative history of section 201 (c) is similarly unenlightening. While Congress did view section 201 (c) as representing "the correct construction of existing law and ... in accord with business practice," 17 no clear exposition of prior treatment of such distributions on the corporate level existed, ${ }^{18}$ and, to the extent any construction did exist, it was inconsistent with the current business practice. ${ }^{19}$ For example, O.D. 479 would charge the par value of the

13. Revenue Act of 1924, §201(c), 43 Stat. 255.

14. Edelstein \& Korbel, The Impact of Redemption and Liquidation Distributions on Earnings and Profits: Tax Accounting Aberrations Under Section 312(e), 20 TAX. L. REv. 479, 483 (1965) [hereinafter cited as Edelstein \& Korbel].

15. 1920-2 Cum. Bull. 29 .

16. Id.

17. H.R. ReP. No. 179, 68th Cong., Ist Sess. 12 (1924); S. ReP. No. 398, 68th Cong., Ist Sess. 12 (1924).

18. Edelstein \& Korbel 483-88.

19. Id. at 487. In Rev. Rul. 70-53I the IRS also makes an assumption as to current business practice by treating unrealized appreciation surplus as part of the capital account. 1970 INT. Rev. BuLl. No. 42, at 9. While there is support for the IRS's position, the treatment of 
shares redeemed to the capital account, and any remaining redemption distribution would decrease the entire pre-1913 surplus. Apparently, if any redemption distribution remained after the first two charges, post-1913 earnings and profits would be charged. ${ }^{20}$ Business practice, on the other hand, would charge the redeemed stock's par value to the capital account and charge the remaining price to combined pre- and post-1913 earnings and profits. Apparently, the only consistent practice was to charge an amount equal to the par value of the stock redeemed to the capital account. ${ }^{21}$

Although there was little legislative history, the IRS took the position that section 201 (c) was an enactment of O.D. 479 and that any redemption price should decrease earnings and profits only after a charge to capital equal to the redeemed stock's par value and a charge to pre-1913 earnings and profits in their entirety. ${ }^{22}$ In John $B$. Stewart ${ }^{23}$ the Board of Tax Appeals refused to accept such an interpretation of section 201 (c). Instead, the Board ruled that an amount equal to the redeemed stock's par value was properly chargeable to the capital account, and the rest of the redemption price was to be charged to post-1913 earnings and profits in their entirety and only upon exhaustion of that amount to pre-1913 earnings and profits. ${ }^{24}$ The Board assumed that the par value of the redeemed shares was the proper charge to the capital account and charged the remaining distribution first to post-1913 earnings on the basis of section 201(b) which required that the charge to earnings and profits be made to the most recently accumulated earnings and profits..$^{25}$

unrealized appreciation is still the subject of formidable debate in business and accounting circles. See, e.g., T. FifLIS \& H. KRIPKE, ACCOUNTING FOR Business LAWYERS 279-327 (1971).

20. See notes 15-16 supra and accompanying text.

21. Support for at least the par value of the redeemed stock being charged to capital account can be found in the House Report which gives an example of stock being redeemed at its par value and states that this woild not offset earnings and profits for later distributions. H.R. REP. No. 179, 68th Cong., 1st Sess. 12 (1924).

22. See the contention of the IRS as presented in John B. Stewart, 29 B.T.A. 809, 810-11 (1934).

23. 29 B.T.A. 809 (1934).

24. Id. at 814 .

25. Id. The Board probably found support for not considering pre-1913 carnings and profits as part of the capital account in the Supreme Court's decision in Helvering v. Canfield, 291 U.S. 163 (1934). In that case the Supreme Court held that pre-1913 earnings and profits wcre accumulations of earnings and were available to offset operating losses arising after March 1, 1913. But see Edelstein \& Korbel 489. There the authors contend that the verbal formula used by the Court camouflaged a deeper policy consideration "that the right to receive pre-1913 earnings and profits tax free could not be exercised so as to permit post 1913 earnings and profits to escape taxation." Id. See note 35 infra and accompanying text. 
The Board of Tax Appeals, in August Horrmann, ${ }^{26}$ was soon forced to modify its position that a charge equal to the redeemed stock's par value should be made to the capital account. Instead, the Board ruled that the proper amount was equivalent to the paid-in capital considered as standing behind each share redeemed at the time of the redemption and was not necessarily equal to the redeemed stock's par value. ${ }^{27}$ The corporate taxpayer had initially issued 400 shares of common stock at $\$ 1,000$ par value. After a recapitalization and a preferred stock dividend, the corporation had outstanding 6,000 shares of no par common and 4,000 shares of $\$ 100$ par value preferred. The corporation redeemed all of the preferred stock for $\$ 400,000$ at a time when it had stated capital of $\$ 30,000$, paid-in surplus of $\$ 370,000$, and substantial pre- and post-1913 earnings and profits. ${ }^{28}$

If the Board had followed Stewart and charged the par value of the preferred stock to the capital account - both the stated capital and paid-in surplus-no amount would remain to reduce earnings and profits. The balance in the capital account, however, would be zero. ${ }^{29}$ The Board, refusing to follow the par value approach of Stewart, recognized that only a portion of the $\$ 400,000$ paid-in capital stood behind the preferred stock and that only such a portion should be chargeable to the capital account. ${ }^{30}$ The remainder, in accordance with Stewart, was to be charged first to post-1913 earnings and profits and then to pre-1913 earnings and profits. The Board viewed the capital structure of the corporation as being increased by the recapitalization and preferred stock dividend to $\$ 1,000,000$ while the statutory capital account, consisting of stated capital and paid-in surplus, remained at $\$ 400,000 . .^{31}$ The Board therefore concluded that the proper charge to the capital account would be the ratio of the par value of the preferred to the value of the total capital structure,

26. 34 B.T.A. 1178 (1936).

27. Id. at $1186-87$.

28. Id. at $1179-81$.

29. This situation existed because the Board ruled that the section 201 (c) capital account was not increased by the issuance of a 150 percent stock dividend and included only the paid-in capital. As part of the dividend the corporation changed its common stock to no par and issued 4,000 shares of $\$ 100$ par value preferred. While the par value of the preferred equalled the total paid-in capital, it did not represent an amount paid in for the preferred. Rather than earmark the capital account to the shares originally distributed, the Board chose to view the accounts of the corporation as standing behind each share proportionately. Id. at 1186.

30. Id.

31. Id. 
$\$ 400,000$ to $\$ 1,000,000$, or 40 percent times the statutory capital account. The Board thus charged $\$ 160,000$ to the capital account and the remaining $\$ 240,000$ to the post-1913 earings. ${ }^{32}$

While the Board of Tax Appeals did not include pre-1913 earnings and profits in the capital account and charged that portion of a redemption distribution not properly chargeable to the capital account first to post-1913 earnings and profits, the Supreme Court took a different position. In Foster v. United States, ${ }^{33}$ the Court held that the proper charge to the capital account included a charge to pre1913 earnings to the extent they existed..$^{34}$ In so ruling, the Court accepted the Service's argument that Congress intended to tax post1913 earnings and profits and not to allow distributions of pre-1913 accumulations so as to permit profits accumulated after that date to escape taxation. ${ }^{35}$ The Court pointed to earlier cases which had held that corporate accumulations prior to 1913 were capital ${ }^{36}$ and ruled that the proper charge to the capital account included the par value of the redeemed shares plus the total remaining purchase price since it did not exceed pre-1913 earnings and profits. ${ }^{37}$ Thus, the Court held that the stock redemption did not reduce post-1913 earnings and profits. Interestingly, the Court's decision implied that the charge to capital account based on pre-1913 earnings is to be charged to the full extent of the pre-1913 earnings and not just to a pro rata share which might be considered as standing behind the stock redeemed. ${ }^{38}$

32. Id. at 1187. August Horrmann also presented a more serious tax problem which the 1954 Code attempted to rectify. The Board, having ruled that the preferred stock dividend was not taxable to the shareholder at the time it was issued, that the later redemption of all the preferred was not taxable at ordinary income rates but was to be treated as an exchange of property, and that a portion of the distribution was to be charged against the carnings and profits account, allowed the $\$ 240,000$ of earnings and profits to be "bailed out" of the corporation at capital gains rates. Section 306 of the 1954 Code was designed to eliminate such preferred stock bail outs, and today the $\$ 400,000$ redemption distribution would be treated as a dividend to the extent of earnings and profits. INT. REv. CODE of 1954, $\S 306$. See B. BitTKER \& J. Eustice, Federal Income Taxation of Corporations and Shareholders, ch. 8 (2d ed. 1966). For a similar factual situation and treatment, see F \& R Lazarus \& Co., 1 T.C. 292 (1942).

33. 303 U.S. 118 (1938).

34. Id. at 121 .

35. Id. at 120. The Court cited Helvering v. Canfield for the policy of not allowing distribution charges which open pre-1913 accumulations to dividend-free distributions. Sce note 25 supra.

36. 303 U.S. at 121 n.9.

37. Id. at 122. See Albrecht, "Dividends" and "Earnings and Profits." 7 TAx. L. REv. 157, 202 (1952) [hereinafter cited as Albrecht].

38. One fourth of the outstanding stock was redeemed for $\$ 1,025,000$. There was a balance 
After Foster, the proper charge to capital account included a charge to pre-1913 earnings and profits before reaching the post-1913 account. Whether to charge the paid-in capital account in its entirety or only pro rata remained in doubt. Soon, the Internal Revenue Service faced the first case not involving pre-1913 earnings and profits. Relying on Foster, the Service argued in William D.P. Jarvis ${ }^{39}$ that a redemption distribution should first be charged to the entire capital account. ${ }^{40}$ Steadfastly holding to the pro rata share of paid-in capital test, the Board of Tax Appeals rejected the Service's contention."

In Jarvis, a corporation formed after March, 1913, initially issued 10,000 shares of $\$ 100$ par value stock for $\$ 1,910,000-\$ 910,000$ was paid-in surplus. Later, 10 percent of the shares were redeemed for $\$ 1,160,000$. The Service contended that the $\$ 1,160,000$ should first be charged to the entire capital account, thus leaving that account with a $\$ 750,000$ balance and not reducing earnings and profits. The Board, however, held that the redemption distribution was chargeable to the capital account only to the extent of 10 percent of the paid-in capital, or $\$ 191,000 .{ }^{42}$ The remainder, $\$ 969,000$, was charged to earnings and profits. The Board viewed Foster as applying only to the situation where a charge to post-1913 earnings and profits would leave pre-1913 earnings and profits available for distribution and favorable tax treatment. ${ }^{43}$

The Internal Revenue Service also contended, in the alternative, that part of the redemption distribution should be viewed as coming

of $\$ 3,725,000$ in the pre-1913 earnings account, and the total par value of the redeemed stock equalled $\$ 50,000$. If a pro rata charge to pre-1913 earnings and profits were made, $\$ 931,250$ and the $\$ 50,000$ par value would be subtracted from $\$ 1,025,000$, leaving $\$ 43,750$ to be charged to earnings and profits. See Edelstein \& Korbel 493-94. The authors note a discrepancy between the Supreme Court figures and the figures in the Government brief. Substantially the same result, however, can be implied with either figure. See also Bennett v. United States, 427 F.2d 1202 (Ct. $\mathrm{Cl}$. 1970), where the Court of Claims held that "pre-1913 earnings and profits are to be fully exhausted before any charge is made to post-1913 earnings and profits." Id. at 1216. But see Treas. Reg. $\S 1.562-1$ (c)(1) (1970), where, for purposes of determining the dividend paid credit under $\S 562$, the charge to capital account includes only the pro rata share of pre-1913 earnings and profits.

39. 43 B.T.A. 439 (1941).

40. Id. at 444-45. See also 1942-2 Cum. Bull. 190.

41. 43 B.T.A. at 445. The Board recognized that Foster overruled Stewart and Horrmann to the extent that those cases charged post-1913 earnings and profits before pre-1913 earnings and profits, but the Board pointed out that Jarvis did not involve pre-1913 earnings and profits and therefore Foster was not applicable.

42. 43 B.T.A. at 445.

43. See note 35 and accompanying text and note 41 supra. 
from unrealized appreciation surplus and that a 10 percent charge to that surplus should be made before earnings and profits were reduced..$^{44}$ The Board rejected this approach and held that the evidence did not show that the redemption premium ${ }^{45}$ came from a reserve not on the corporation's accounting records. ${ }^{46}$ The Fourth Circuit affirmed, adopting almost in its entirety the opinion of the Board.47

The Service, rebuffed in its attempts to charge the redemption distributions first to the entire paid-in capital account, ${ }^{48}$ finally acquiesced to the Jarvis decision. ${ }^{49}$ In so doing, the Service apparently accepted the principle that a pro rata share of paid-in capital was deemed to stand behind stock redeemed and that the pro rata share was properly chargeable to the capital account. The remaining distribution, therefore, was to be subtracted from earnings and profits. $^{50}$

44. 43 B.T.A. at $445-46$.

45. The redemption premium is the excess of the redemption distribution over the sum of the redeemed stocks' pro rata share of paid-in capital and earnings and profits.

46. Helvering v. Jarvis, 123 F.2d 742, 746 (4th Cir. 1941), affg 43 B.T.A. 439. See Edelstein \& Korbel 497.

47. Helvering v. Jarvis, 123 F.2d 742 (4th Cir. 1941).

48. These attempts included F\&R Lazarus \& Co., 1 T.C. 292 (1942), A.H. Rice, 1 T.C.M. 245 (1942), and William D.P. Jarvis, 43 B.T.A. 439 (1941).

The IRS was also rebuffed in its attempts to have a liquidation distribution charged in full to the capital account. In Woodward Investment Co., 46 B.T.A. 648 (1942), part of the assets of a corporation were distributed pursuant to a plan of liquidation to be completed within two years. The corporation claimed a dividends-paid credit based on the distributions, and a question arose coneerning the manner of determining the credit. Under the then existing Code, the credit equalled the amount properly chargeable to earnings and profits, and the applicable regulations referred to the forerunner of section 312(e) for determining that charge. The Board held that the proper charge to earnings and profits equalled the ratio of the earnings and profits over the sum of the tax basis of the paid-in capital and earnings and profits times the tax basis of the assets distributed. The Board could not follow the Jarvis method since no shares were redeemed. The IRS viewed Jarvis and Woodward as consistent and as reflecting "necessary differences in the application of a general principle to different types of situations." 1942-2 CUM. BuLL. 190.

Some commentators have adopted the view that the Woodward approach applicd to a Jarvis-like stock redemption would call for a charge to earnings and profits only equal to the redeemed stocks ratable share of that account. See B. BITTKER \& J. EusTiCE, supra note 32, at $\S 7.85$; Albrecht 206. Woodward, however, is limited to distributions where shares arc not redeemed, and, even if the Woodward analysis were applied in a redemption, the charge to earnings and profits would exactly equal the redeemed stock's pro rata share only in fortuitous circumstances. Equality would be achieved only when the ratio of the basis of the assets distributed to the total basis of the corporate assets equalled the ratio of the stock redeemed to all the outstanding stock. See Edelstein \& Korbel 514.

49. 1942-2 Cum. Bull. 10. Rev. Rul. 70-53 I has withdrawn acquiescence. See note 8 supra.

50. Unresolved, however, is the question of whether the charge to pre-1913 earnings is pro rata. But see Bennett v. United States, 427 F.2d 1202 (Ct. Cl. 1970). See note 38 supra. 
The 1954 Code and Subsequent History of Section 312(e)

Section 312(e) of the 1954 Code enacted prior law substantially unchanged. ${ }^{31}$ While consideration was given to changing the statutory charge to capital account, ${ }^{52}$ Congress rejected the change and indicatcd that "the existing administrative practice . . . has been successful in achieving correct results." ${ }^{33}$

A collateral but perhaps informative action was taken by Congress in enacting the Revenue Act of 1962. This act amended section 1246 of the 1954 Code so as to provide that upon the redemption or liquidation of an American shareholder's interest in a foreign investment company, ordinary income treatment would result "to the extent of the taxpayer's ratable share of the earnings and profits of such corporation . . . ."54 The Revenue Act of 1962 also provided in subsection $312(l)(3)$ that the foreign investment company would be entitled to a charge to earnings and profits in an amount "not in excess of the ratable share of the earnings and profits of the company accumulated after February 28, 1913, attributable to the stock so redeemed." 55 Previous to this, redemption and liquidation distributions of foreign investment companies would have been treated under section 312 (e). Congress, however, found it necessary to order separate treatment for both the shareholder and corporation for certain non-dividend distributions of foreign investment companies. Presumably, the treatment in subsection $312(I)(3)$ was thought by Congress to differ in some way from the treatment that such distributions would have received under section 312(e).

The IRS in 1964, apparently not viewing section $312(l)(3)$ as indicating that a different treatment is called for under section 312 (e), issued an unpublished ruling under section 3I2(e) substantially duplicating the language of section $312(I)(3)$. The ruling stated that the proper charge to earnings and profits under a section 312(e) redemption distribution should not exceed the ratable share of the earnings and profits attributable to the stock redeemed..$^{56}$ The Service's recent Revenue Ruling 70-53I publicly affirmed their

51. See text accompanying notes 16-17 supra.

52. See H.R. Rep. No. 1337, 83d Cong., 2d Sess. A 95-96 (1954).

53. S. ReP. No. 1623, 83d Cong., 2d Sess. 47 (1954).

54. Revenue Act of 1962, § 14(a), 76 Stat. 1036, amending INT. REv. Code of $1954, \S 1246$.

55. Revenue Act of 1962, $\S 14(\mathrm{~b}), 76$ Stat. 1041, amending INT. REV. CODE of $1954, \S 312$.

56. See 21 J. Taxation 127, 171 (1964). 
change of position, rejecting 30 years of case law which has survived several major and minor redraftings of the Internal Revenue Code.

Revenue Ruling 70-531

The new ruling as to the proper charges under section 312(e) redemption distributions can be seen to vary in several respects from the historical application of that section. First, the charge to the capital account includes the pro rata portion of paid-in capital at its basis for Federal income tax purposes and not necessarily at its fair market value at the time it was paid-in. ${ }^{57}$ Second, the charge to earnings and profits equals the pro rata portion of the total earnings and profits attributable to the redeemed shares rather than the amount remaining after the charge to the capital account. Third, a portion of the redemption price is charged off against an unrealized appreciation surplus or depreciation deficit and thus not charged to an actual account of the corporation.

The use of basis rather than par value or fair market value paid in may be a more apparent than real change. In each of the cases in which the Board of Tax Appeals spoke in terms of a charge based on par value of stock, the facts indicated that the tax basis of the property-usually cash - contributed for those shares equalled the par value and any paid-in surplus. ${ }^{58}$ When the Board was faced with cases where the par value did not reflect the corporate tax basis of the property contributed for the stock, the Board determined the actual portion of the tax basis value of the assets which stood behind the shares and made the appropriate pro rata charge..$^{59}$

A simple example can illustrate the importance of the basis versus the fair market value or par value charge. Assume A and B contribute properties to Corporation $\mathrm{X}$, each contribution having a fair market value of $\$ 200$ and a basis of $\$ 100$ and $\$ 200$ respectively. Pursuant to section 362, B's basis becomes the basis for the corporation, and A's basis, $\$ 100$, likewise becomes the corporation's basis. In return for their contribution, $A$ and $B$ both receive one share of $\$ 200$ par value

57. 1970 INT. Rev. Bull. No. 42 , at 10.

58. See, e.g., Foster v. United States, 303 U.S. 118, 119 (1938); William D.P. J̣arvis, 43 B.T.A. $439,440,445$ ( 1941 ); John B. Stewart, 29 B.T.A. 809, 810 (1934).

59. See F \& R Lazarus \& Co., 1 T.C. 292, 300 (1942); August Horrmann, 34 B.T.A. 1178, 1179 (1936). See notes 25-30 supra and accompanying text. Woodward Investment Co., 46 B.T.A. 648 (1942), considered the proper charge to earnings and profits upon a liquidation distribution. In making its calculations the Board appeared to use the tax basis of the corporate accounts. Id. at 649,652 . 
stock. Corporation $\mathrm{X}$ sells $\mathrm{A}$ 's property increasing earnings and profits by the $\$ 100$ gain. If $X$ now redeems $A$ 's stock for $\$ 200$ and a charge to the capital, account is determined by the par value, the entire $\$ 200$ would be charged to the capital account with no reduction in earnings and profits. On the other hand, if the charge to capital account is determined by the basis in the property contributed for the shares redeemed, there would be a $\$ 100$ charge to capital and a $\$ 100$ charge to earnings and profits, a more accurate reflection of the economic realities of the transaction. The corporation is left with a zero balance in earnings and profits instead of a $\$ 100$ balance, and B is left with an interest in a $\$ 200$ asset with a $\$ 200$ tax basis. It is, therefore, more accurate for the charge to capital to include the pro rata share of the corporation's tax basis for the paid-in capital standing behind the redeemed shares rather than the fair market value of the property contributed for the shares. ${ }^{60}$

The Service, in Revenue Ruling 70-531, defines the proper charge to capital account so as to insure a pro rata charge to earnings and profits. ${ }^{61}$ Thus, in every redemption distribution the charge to earnings and profits will be the pro rata share of earnings and profits attributable to the shares redeemed. Similarly, there is a charge to the capital account equal to the pro rata share of paid-in capital valued at its tax basis. Any distribution in excess of the sum of the pro rata shares of earnings and profits and paid-in capital is charged to an unrealized appreciation surplus which is considered part of the capital account for section 312(e) purposes. ${ }^{62}$ The charge to unrealized appreciation is apparently made regardless of whether such an appreciation can be justified. ${ }^{63}$

60. See Edelstein \& Korbel at 571; Nesson, Earnings and Profits Discontinuities Under the 1954 Code, 77 Harv. L. Rev. 450, 458 (1964).

The example given would earmark the capital contributed for any particular share and, upon a subsequent redemption, charge the capital account with an amount equal to the basis of the capital contributed for each share. This, of course, would necessitate detailed accounting, and there is some language in August Horrmann which would indicate that earmarking would not have been acceptable to the Board of Tax Appeals when that case was decided. 34 B.T.A., at 1186. See note 29 supra. Furthermore, the tax basis approach taken in the other cases was based on a pro rata share of the total tax basis rather than on a charge to capital account determined by earmarking portions of the capital account to particular shares redeemed.

If the pro rata share of the tax basis of the capital account were used in the textual example, the charge to the capital account would be $\$ 150$ and only $\$ 50$ would be charged to earnings and profits.

61. 1970 INT. Rev. BuLl. No. 42, at 10.

62. Id. at 9 .

63. No mention is made in the Revenue Ruling of whether the fair market value of the assets 
This leads to another problem. Under the Revenue Ruling, the charge to the unrealized appreciation account is forever lost. A corporation, in fact, has no such account and never transfers any balance in such an account to other corporate accounts so as to alter its tax liability. Yet, the amount charged to unrealized appreciation surplus is, theoretically, a payment by the corporation to the redeemed shareholder for the right to receive the appreciation attributable to his shares whenever that appreciation is realized by the corporation. In a sense, the corporation is paying for and should receive a basis in the unrealized appreciation and should be able, in some way, to charge today's payments against the corporate gain which will arise when the appreciation is finally realized. This has, in the past, been achieved by reducing earnings and profits presently on the basis of the excess paid in redemption over the redeemed shares' pro rata portion of paid-in capital. ${ }^{64}$ Under such an approach, when the future earnings are secured, they will increase earnings and profits, but to some extent they will only be replacing the earnings and profits reduction made on the basis of the earlier redemption distribution. One major drawback of this historic approach ${ }^{65}$ is that it allows the remaining shareholders the immediate advantage of a large earnings and profits reduction and the possibility of bailing out assets without having the distribution treated as a dividend. ${ }^{66}$ Still another drawback is that the assets which have appreciated may never be sold by the corporation or may only be sold after a long time. ${ }^{67}$ Thus, the advantage of the earnings and profits reduction continues without ever being offset by the gain from the sale of the asset. A further drawback is that the charge to earnings and profits may not in fact reflect any similar asset appreciation which will result in future gain to the corporation. ${ }^{68}$ Thus, while there is little historic support for the

need reflect an increase in value. Thus, a redemption premium which represents a payment for control or for a future earnings flow and not any appreciation in assets would be charged to the unrealized appreciation surplus.

64. Evidently, on the theory that the high market value of the stock represents unrealized appreciation in the corporate assets and that when these assets are sold the earnings account will be increased, the 1954 Code requires that the capital account shall be reduced in proportion to the number of shares redeemed over total shares . . . and that the remainder be charged against earnings and profits. . . Nesson, supra note 60 , at 459.

65. See notes $39-49$ supra and accompanying text.

66. See note 32 supra.

67. The appreciated assets are often those vital to the business and as long as the business is carried on the assets will not be sold.

68. See generally D. Herwitz, Business Planning 1-29 (1966). 
Service's position in Revenue Ruling 70-531, ${ }^{69}$ the ruling does represent an approach designed to overcome certain inaccuracies historically allowed in the redemption distribution charges. The real problem is that the Service has not carried its recommended treatment to its logical conclusion.

Treatment of the Charge to Unrealized Appreciation Under Section 312(e) and Revenue Ruling 70-53I

A redemption should be viewed as a purchase of an interest in a corporation. ${ }^{70}$ If a 50 percent interest is being purchased by a corporation in itself, through a redemption, the redemption distribution should equal 50 percent of the fair market value of the corporation. Two approaches might be taken in valuing the corporation, and both provide insight into how the redemption distribution should be charged to the corporation's various accounts. ${ }^{71}$

The first approach, and the one the Revenue Ruling apparently takes, is to treat a distribution in redemption of a 50 percent interest as the price paid for 50 percent of the fair market value of the assets of the corporation. This would justify a 50 percent charge to earnings and profits, a 50 percent charge to paid-in capital at its tax basis, and any remaining purchase price would theoretically represent 50 percent of the unrealized appreciation of the assets of the corporation. ${ }^{72}$

69. See notes $48-49$ supra and accompanying text.

70. For a general discussion concerning the analogous treatment of liquidations as the purchase of an interest see Bittker \& Redlich, Corporate Liquidations and the Income Tax, 5 TAX. L. Rev. 437 (1950); Darrell, Corporate Liquidations and the Federal Income Tax, 89 U. PA. L. REv. 907 (1941).

71. Edelstein and Korbel discuss alternative approaches to charges to earnings and profits in a section 312(e) redemption distribution. One approach centers on minimizing bail outs and calls for the distribution to be charged to the capital account in its entirety before reducing earnings and profits. The other approach attempts to achieve tax equity for the remaining shareholders. This is accomplished by insuring that the potential tax liability of the remaining shareholders through possible corporate distributions after the section 312 (e) charge equals the remaining shareholders' pro rata share of the potential tax liability before the redemption distribution. See Edelstein \& Korbel 517-26.

72. Some credence is lent to this approach by section 311(d) of the 1954 Code added by section 905(a) of the Tax Reform Act of 1969, 83 Stat. 487. Under section 311(d), if a corporation redeems some of its stock by distributing appreciated property, the corporation must recognize gain to the extent the fair market value of the property exceeds its tax basis. This gain gives rise to a simultaneous increase and decrease in the earnings and profits account. Under section 312(c)(3), the gain recognized increased earnings and profits while under 312(e), as interpreted by Rev. Rul. 70-531, the earnings and profits are decreased by the redeemed stock's pro rata share. The net effect is to leave in the earnings and profits account a portion of 
Adopting this approach requires more than determining the above charges. Because the corporation is forced to charge off a portion of the redemption distribution against unrealized appreciation, the corporation should be entitled to utilize this amount upon a later realization of the appreciation of the assets. Otherwise, if the so-called charge to unrealized appreciation is lost upon a subsequent sale by the corporation of the appreciated assets, the total gain will be included in the earnings and profits account and thus increase that account by 100 percent of the appreciation when, in fact, it should only be increased by 50 percent, the other 50 percent having been previously distributed in the redemption. ${ }^{73}$

A solution to this inequity toward the remaining shareholders might be achieved by allowing a credit, equal to the charge which is made to the unrealized appreciation surplus upon the redemption, to be applied against the addition to earnings and profits on the subsequent sale of an asset by the corporation. Thus, if an asset is sold and a capital gain of $\$ 100$ realized, 50 percent of the gain would be charged to earnings and profits and the other 50 percent would be applied against the unrealized appreciation charge made at the time of redemption. The same would happen upon the sale of any asset until the account for the charge to unrealized appreciation is eliminated. ${ }^{74}$

While the asset valuation approach does reflect economic realities by reducing the unrealized appreciation charge to earnings and profits upon the later sale of a corporate asset which results in gain, and while it does avoid a large initial charge to earnings and profits which would otherwise allow a possible bail out, the asset valuation approach still contains drawbacks. First, the charge may not be used for a long period of time, if ever, ${ }^{75}$ and in the interim the assets may depreciate

the gain recognized under 31 (d) equal to the remaining stock's pro rata share of that gain and attribute to the redemption price the pro rata share of the apprcciation attributable to the shares redeemed. For a discussion of section $31 \mathrm{l}(\mathrm{d})$, see Note, Section $31 /(\mathrm{d})$ of the Internal Revenue Code. Earnings and Profits and Their Relation to Section 1248 Transactions, 55 MiNN. L. REv. 321 (1970).

73. The 100 percent and 50 percent figures assume that the assets neither appreciate nor depreciate between the time of the redemption and the time gain is rcalized upon the sale of the assets. Subsequent appreciation or depreciation, however, does not affect the principle that the full gain should not be charged to earnings and profits because the corporation has had to pay for part of it in the form of a redemption premium.

74. 1t may be possible to refine this approach so that a subsequent gain realized on assets acquired after the redemption distribution would not affect the unrealized appreciation account. However, this may not be feasible due to administrative considerations.

75. See note 67 supra and accompanying text. 
in value so that no gain will be available to apply against the unrealized appreciation charge upon a subsequent sale. ${ }^{76}$ Second, the premium in the redemption distribution may not reflect asset appreciation. ${ }^{77}$ The second drawback leads to another possible approach of treating the charge to unrealized appreciation and, in the process, provides a method of solving the first deficiency.

The second way of examining the redemption distribution is that it represents a valuation of the interest redeemed based on the ordinary future earnings of the corporation..$^{78}$ This earnings capitalization approach is especially appropriate when the redemption price varies significantly from a valuation based on the fair market value of the assets attributable to the interest redeemed. This is often the case where a purchase is of the corporation as a business unit capable of returning profits in the future rather than as a conglomerate of assets available for sale. Thus, while the fair market value of the net assets of a corporation may onjy be $\$ 200$, a redemption of a 50 percent interest in the corporation for $\$ 200$ may take place. The high redemption price does not reflect asset appreciation as yet unrealized but rather represents the price paid for a 50 percent interest in a future earnings flow.

If the earnings capitalization approach is used, the premium upon redemption represents a portion of the future earnings flow. Therefore, any excess in the redemption distribution over the shares' pro rata portion of earnings and profits and paid-in capital should be used to offset future increases in earnings and profits resulting from future earnings of the business. Otherwise, the total future earnings would be included in earnings and profits, and the remaining shareholders would be taxed upon a distribution to the full extent of the distribution when, in fact, the corporation already has paid some future earnings out in the redemption. ${ }^{79}$

The proper charge to earnings and profits would arguably take place as follows: ${ }^{80}$ Assume that 50 percent of the shares of a

76. This objection might be overcome by increasing the basis of the assets for earnings and profits purposes by the amount of the unrealized appreciation, thus enabling the corporation to rcduce the earnings and profits account if the assets decline in value upon sale. However, this approach may create administrative difficulties.

77. See A. Dewing, Financial Policy of Corporations 281-82 (5th ed. 1953). See notes 63 and 66 supra and accompanying text.

78. See generally D. Herwirz, supra note 68, at 13-19; Albrecht 206.

79. Halpern, Carryovers of Earnings and Profits, 18 TAX. L. REv. 292-93 (1963).

80. See Edelstein \& Korbel $521-25$. 
corporation are redeemed for $\$ 300$. The paid-in capital account is $\$ 100$, and the earnings and profits account is also $\$ 100$. A pro rata charge of $\$ 50$ to each leaves each account with a $\$ 50$ balance. The remaining $\$ 200$ premium upon the distribution reflects the price paid for 50 percent of the expected future earnings discounted to their present value. The following charges should be made. In year one, the first year after the redemption, the amount chargeable to the earnings and profits account because of that year's business activity ${ }^{81}$ would be reduced by 50 percent - the percent of outstanding stock redeemed in the year of redemption. This reduction would then be discounted back to its value in the year of the redemption and subtracted from the $\$ 200$ premium. In the second year after the redemption the same procedure would take place, and the amount of the reduction would be discounted back in the same manner and subtracted from the premium. This would continue until the entire premium is eliminated.

\section{Conclusion}

The earnings capitalization approach avoids an unnecessarily large initial charge to earnings and profits and lessens the potential for the bail out of corporate earnings. It insures that the charge to unrealized appreciation required by Revenue Ruling 70-531 will not be lost upon a subsequent sale of appreciated assets and probably accurately reflects current business practices in valuing interests in corporations. ${ }^{82}$ Therefore, if the courts accept the dictates of Revenue Ruling 70-531, they should also allow future reductions to the earnings and profits account in conformity with the earnings capitalization approach set forth above, thus insuring that a redeeming corporation does not lose the benefit of the required charge to unrealized appreciation. In the meantime, however, the legality of the new ruling is certainly open to question.

81. The reduction should be made on income after federal income taxes. The redemption premium reflects earnings of the corporation which would be available to the shareholders after taxes.

82. See generally Gould \& Coddington, How Do You Know What Your Business is Worth?, SBA Management Aid No. 166 (1964), reprinted in D. HeRwitz, supra note 68, at 1. 